\title{
Business Financial Performance In The Context Of Customer Satisfaction Management
}

\author{
Suchánek PETR ${ }^{*}$, Činčalová SIMONA ${ }^{2}$, Kotoučková HANA ${ }^{3}$, Dvořáková STANISLAVA ${ }^{4}$ \\ 1,2,3,4 College of Polytechnics Jihlava, Tolstého 16, Jihlava, 586 01, Czech Republic \\ Email: petr.suchanek@vspj.cz'1, simona.cincalova@vspj.cz², hana.kotouckova@vspj.cz ${ }^{3}$, stanislava.dvorakova@vspj.cz ${ }^{4}$ \\ * Corresponding Author
}

Received: 13.08.2021 $\quad$ Accepted: 17.10.2021 $\quad$ Published: 01.12.2021 $\quad$ DOI: 10.47750/QAS/22.185.17

\begin{abstract}
The article focuses on the research of the relationship between performance in financial terms and customer satisfaction management in the company. Customer satisfaction management is understood as a process aimed at determining customer satisfaction and dissatisfaction in the form of backflows (from the customer), which is used throughout the company so that the company acquires and uses customer knowledge to change (innovate) in the company (whether in the form of process or product innovation). Through a change in customer satisfaction management, the company's financial performance is to be improved. The research is based on analyses of the relationships of selected factors of customer satisfaction management and their partial variables to the financial performance of the company. The article aims to identify the factors of customer satisfaction management that affect the financial performance of the company. A partial goal of the article is to identify the causes of the identified financial performance of the company, through quantities within the examined factors of customer satisfaction management. The research is carried out quantitatively using a questionnaire on a sample of 113 companies from various industries in the Czech Republic. Financial performance is assessed as profitability subjectively, by respondents to research, which consisted of managers of the surveyed companies. The relationships of individual factors and quantities were analyzed first using factor and then regression analysis. Statistical significance was verified by appropriate standard tests (t-test) and the significance of the model by the coefficient of determination. The results show that financial performance is influenced by customer satisfaction management and depends primarily on reverse flow management (from the customer), innovation and knowledge, the source of which is the customer and the internal customer satisfaction management support system.
\end{abstract}

Keywords: business performance; customer satisfaction management; sources of innovation; knowledge management; backflow management.

\section{Introduction}

This research focuses on analyzing the relationship between financial performance and customer satisfation management. The research is based on analysis of partial relationships of selected factors of customer satisfaction management (finding customer satisfaction and dissatisfaction, customer backflow management, knowledge management and innovation management in the company) to the company's performance. Performance is represented by profitability (compare with Cristian, Monica, 2017; Veronica, 2017). The relationship between performance and customer satisfaction has been demonstrated (Eklof, Podkorytova, Malova, 2018; Jyoti, Kour, Sharma, 2017; Mittal, Frennea (2010), performance and knowledge (Abualoush et al., 2018), performance and backflows (Larsen et al., 2018) and performance and innovation (Neely, Hii, 1998) Some research has also looked at the combined effects of several of the above factors on performance, such as customer satisfaction and backflows (Hammes et al., 2020) or knowledge and innovation (Alrubaiee et al., 2015) or knowledge, innovation and customer satisfaction (Gholami et al., 2013).

However, the authors have not yet examined the complex effect of these factors on performance. Although similar complex models exist, such as the Balance scorecard (Kaplan, Norton, 2001) or the EFQM excellence model (Nabitz, Klazinga, Walburg, 2000), these models are primarily focused on measuring performance and not on managing customer satisfaction. Although the above models take into account customer satisfaction, this satisfaction is only one of the elements of the company's performance evaluation system, while the goal of the models is primarily to measure customer satisfaction. However, our research is focused on what to do with the information about the detected customer satisfaction, resp. how and where to use them in the management of the company so that the financial performance of the company increases. In this regard, we do not address how to measure customer satisfaction, as we believe that based on several pieces of research (see, for example, Fornell et al., 1996 or Cassel, Eklöf, 2001) the company will be able to handle it, but what to do with this information.

Unlike quality management, we put the customer first, we look for factors (in the form of activities) that are related to customer satisfaction and we look for a management system that will increase customer satisfaction. The basis of our concept of customer satisfaction management is thus in line with Piskóti \& Nagy (2009). However, our system is more specifically targeted, especially within the company for its processes that relate to customer satisfaction. A 
comprehensive management system is then what Customer satisfaction management is similar to Quality management and how it differs from the concept of Piskóti \& Nagy (2009). As part of our research, it was not possible to analyze the entire company (all areas and processes) and therefore the research focused only on a few selected areas that are closely related to the transmission and use of customer satisfaction information in the company.

\section{Theoretical Framework}

Performance and its management have long been a researched issue, even in the context of customer satisfaction (Chen and Cheng, 2007) or innovation (Munizu and Hamid, 2018). In general, performance can be defined differently, so it depends on the context, which then allows you to specify performance (compare with Ferraz and Gallardo-Vázquez, 2016). The subject of the research presented in this paper is the company, so performance needs to be defined in the context of the company. Drucker (1992) defines performance as the final test of any organization. Hult et al. (2004) define performance similarly, but more specifically concerning financial indicators, "as the achievement of organizational goals related to profitability and sales and market share growth, as well as the achievement of the company's general strategic goals".

Business performance can be monitored through business results or their quantification (Neely et al. 2005). In this context, Neely et al. (2005) understand performance as the degree to which customer requirements are met (effectiveness) or as the degree of economic use of a company's resources that leads to given customer satisfaction (efficiency). Thus, performance (in the economic sense) is linked to customer satisfaction.

Performance is usually measured objectively using secondary (accounting) data, as these data are relatively reliable (Tosi et al. 2000). Quantitative measurement of business performance based on accounting data is also relatively widespread (compare eg with Gunasekaran et al., 2005, Gupta, Galloway, 2003). However, subjective performance measurement is also relatively commonly used in research, especially in the case of unavailability of objective data (Zulkiffli, Perera, 2011) or their unreliability (Dess, Robinson Jr, 1984) or the ability to compare business performance across sectors and contexts (Song et al., 2005). Research has shown that the results of subjective and objective performance measurements correspond to each other (Dess, Robinson Jr, 1984; Wall et al. 2004). Some research even speaks in this sense of a strong correlation between the two methods of measurement (Dawes, 1999). Subjective performance measurement is in principle very similar to objective measurement in the sense that it uses the same (usually absolute) variables (eg sales, costs or profit), either alone (per enterprise) or concerning competition (cf. Deshpandé et al 1993, Narver, Slater, 1990, Deng, Dart, 1994, Vij, Bedi, 2016).

Businesses use customer satisfaction as a measure of successful performance and competitive position in comparison with the competition (Sun and Kim, 2013). At the same time, Butler (2000) warned almost 20 years ago that customer knowledge, which can be used to improve products and thus increase satisfaction, was not given enough attention, and believed that companies rarely make full use of customer knowledge.

One of the most cited definitions of customer satisfaction is to consider it as the evaluation of a product or service after consumption (Mittal and Frennea, 2010). Evaluation refers to the perceived magnitude of the difference between previous expectations related to the functions and characteristics of a product or service and its actual performance as perceived during purchase, delivery, and after consumption (Tse and Wilton, 1988; Kobylanski et al, 2011). When the expected quality is delivered, customers are satisfied and improved quality reduces product return, increases satisfaction, and can promote loyalty and repeat purchases (Guo et al, 2004).

Concerning the focus of the article, it is important to focus on the process of determining customer satisfaction. Research by Muffatto and Panizollo (1995) reveals two important findings. The first is that the interdependencies between customer satisfaction management processes across relevant functions need to be explored and analyzed to take the right actions for improvement. The second finding is that the most widespread concept of customer satisfaction is mainly based on factors related to the monitoring of customer satisfaction itself, and is therefore largely independent of internal processes. It can be added that to take the right measures to improve processes, it is necessary to detect and identify not only the deviations themselves but especially the causes of these deviations (Reichheld, Sasser, 1990). At the same time, it is appropriate to focus on the system, its elements and quantities that affect it, because according to Pakdil et al. (2009 according to Deming, 1986) 95\% of deviations are caused by systemic causes.

Effective measurement should be designed and implemented to determine and understand customer satisfaction. Effectiveness should address issues of formalization, measurement frequency, measures themselves, as well as sampling (Morgan et al, 2005). Measurement should be a continuous process, as a wide range of methods, tools and measures provide better insight into the complex area of customer satisfaction (Grigoroudis and Siskos, 2009). Because customer satisfaction is changing, the question arises when resp. how often to measure this satisfaction. It cannot be stated unequivocally that the more often the feedback is obtained, the better the product (service) provided. Although the authors do not agree on the frequency of feedback, they agree on its regularity, ie. that feedback, including customer satisfaction, should be collected regularly (cf. Casas - Arce et al., 2017, So, et al., 2013). In addition to customer satisfaction, it is important to address customer dissatisfaction. The dissatisfaction of the practitioner can be defined as "as resulting from contemplating what falls short of one's wishes or expectations" (Gilly, 1979). At first glance, customer dissatisfaction is the opposite of customer satisfaction (Mittal et al., 1999), however, dissatisfaction can be induced earlier than satisfaction and can last longer because customers tend to maintain negative feelings about a particular brand for longer (Colgate, Danaher, 2000). As a result, customer dissatisfaction does not have to be just the opposite of customer satisfaction (Souca, 2014), and it is thus offered to examine this factor separately.

Backflows can be characterized as flows that occur at the end of the so-called forward supply chain, flowing back to the supplier, whether as a distributor, producer or supplier of raw materials and materials, while the backflow can monitor and copy the forward flow, but can also " circumvent "some of the links in the chain (De Brito, 2003; Fernández Quesada, 2003). Backflows are most often formed by tangible products, but they can also be formed by intangible objects, resp. intangible flows, which may include, in particular, information and knowledge and financial flows (Kopicki et al., 1993; Giuntini, Andel, 1995; Kroon, Vrijens, 1995; Thierry et al., 1995). Information flows can be partially replaced by the term communication flows, although communication is a two-way act (Kumar et al., 2009). Backflows are perceived by companies more as a problem, however, several empirical studies point to the fact that effective and efficient 
management can have many positive effects on the company's performance. Such backflow management can lead to cost reductions (either by reducing the total volume of backflows or by involving different practices to reduce them in different backflow-generating or backflow-reducing processes) and, conversely, to increased productivity and ultimately profitability (Stock et al., 2006; Stock, Mulki, 2009). In addition to working with costs, the most common reasons for increasing profitability in reverse flow management may be increasing customer satisfaction (Petersen, Kumar, 2010), positive whispering and then gaining new customers and increasing sales (Minnema et al., 2016), increasing customer loyalty and Improving corporate image despite corporate social responsibility (CSR) image (De Brito, 2003; Mollenkopf et al., 2007; Russo, Cardinalli, 2012), which is proactively interested in reverse flows (Kuik et al., 2011; Mollenkopf et al., 2011). There is also a positive impact in terms of improving product quality in processes when feedback flows are perceived as a source of feedback on value processes and outputs from value processes in the company's internal environment and supply chain (Russo, Cardinalli, 2012). It can not only improve quality but also innovate products and processes, ie support the innovative behaviour of companies (Un, Cuero-Cazurra, 2007).

As Fundin and Bergman (2003, p. 55) point out, referring to Shewhart's work, which began in the 1930s with a study of quality management knowledge, knowledge of what makes customers excited, what satisfied and what dissatisfied, "is critical to success in a highly competitive environment Knowledge management, if implemented effectively, has several positive effects on the operation of the company. Among others, Darroch (2005) and Van der Spek and Carter (2005) give some of the most important examples - impact on competitive advantage, improved financial performance, innovation, the anticipation of problems, improved learning processes in the organization and better use of information, improved processes, increased satisfaction employees and increase their skills and increase customer satisfaction. Knowledge management also has a positive impact on building and maintaining relationships with customers and suppliers and on the necessary integration and cooperation with these stakeholders in the supply chain (Škapa and Klapalová, 2019).

Knowledge management summarizes the key processes that group the efforts of companies with the knowledge to work, develop and use them to achieve the goals of the organization. These processes include: capturing and acquiring knowledge, gathering, integrating and creating knowledge, experimenting with knowledge, transforming, organizing, transferring, sharing and disseminating, storing knowledge, and applying and exploiting knowledge. There are two categories of the knowledge transfer mechanism. Codification, which means the transfer of knowledge into a tangible form and its capture in databases or documents, and personalization, which means the transfer of knowledge between people (Hansen et al., 1999, cited in Fundin and Bergman, 2003). In addition to the sub-processes related to knowledge, knowledge management also contains the necessary "infrastructures, skills and managerial activities that support and improve knowledge-related processes" (Andreeva and Kianto, 2012, p. 619). It is the set of knowledge-oriented management activities and practices that enable a company to create and deliver value through its knowledge assets that are the core of knowledge management (Andreeva and Kianto, 2012).

Innovation (as an output of innovation processes) and innovation or ability to innovate, especially in the context of knowledge management and learning, are another factor that is attributed the role of one of the key forces of success and competitiveness of enterprises, and thus with a positive impact on performance. (e.g. Damanpour, 1996; Calantone et al, 2002; Johanessen, 2008; Jimenez and Sanz-Valle, 2011).

Several empirical studies show that it is mainly product and process innovations that positively affect business performance, probably due to the possibility of faster and more measurable results of these innovations compared to organizational or marketing innovation (Atalay et al, 2013) or administrative (Subramaniam and Nilakanta, 2006). However, it should be noted that the relationship between innovation, business innovation and performance, respectively. competitiveness and success may not always be straightforward and unambiguous (cf. Cho, Pucika, 2005; Rosenbusch et al, 2011; Prajoga, 2006). Some research has also shown a positive effect of innovation on customer satisfaction and subsequently also a positive effect on company performance (Rubera, Kirca, 2017).

\section{Methodology and Data}

A questionnaire was used which contained a total of 39 questions divided into 4 parts: basic data (8 questions); business performance ( 2 areas, both containing 4 questions); and quality management (23 questions).

Out of the total number of questions, 7 were open questions (basic data) and 32 were closed questions. Out of the closed questions, 1 was dichotomic (yes or no - basic data), the other 31 questions were scale questions (with a 7 degree scale). Out of the scale questions, 10 (knowledge capital) were evaluated on a Likert scale (1-completely disagree to 7-completely agree) and the other 21 questions were evaluated on a 7-degree scale where 1 meant the lowest possible rating and 7 the highest possible rating.

Multiple linear regression was used to analyze the relationships between several independent variables and one dependent variable. In multiple linear regression, the values of the dependent variable are searched for from a linear combination of the values of two or more independent variables. The formula for this type of regression is as follows (Pallant, 2010; Mareš et al., 2015):

$$
\mathrm{Y}=\mathrm{b}_{0}+\mathrm{b}_{1} \mathrm{X}_{1}+\mathrm{b}_{2} \mathrm{X}_{2}+\mathrm{b}_{3} \mathrm{X}_{3}+\mathrm{b}_{4} \mathrm{X}_{4}
$$

Regression analysis aims to estimate the influence of each of the independent variables $X i$ on the dependent variable $Y$. The strength of this influence is determined by the coefficient $\mathrm{b} i$ in the regression equation. These are non-standardized coefficients. Using standardized beta coefficients, it is possible to determine the relative strength of the influence of individual variables on the dependent variable. We find out which variables have the greatest influence on the variance of the dependent variable (the value of the beta coefficient is the largest) and which have the smallest effect. In the results of the linear regression, we are also interested in the coefficient $R \wedge 2$, which says how much of the variance of the dependent variable is explained by the independent variables. Besides, the Adjusted $R^{\wedge} 2$ coefficient takes into account the number of variables that enter the model (for more details, see Mareš et al., 2015).

Another method used is factor analysis. Its main goal is to reduce data. If there are a large number of variables, factor analysis selects those variables that are similar and creates a new variable from them - the factor. Factor analysis works with cardinal variables or ordinal variables with a longer scale. The aim is to find out whether it is possible to reduce more variables to a few factors and create new variables from them. The main component method is used for this. To find the 
factors, it is necessary to decide how many factors to work with. For this purpose, the so-called eigenvalues are calculated and a Cattel scree plot is constructed. The number of factors that have an eigenvalue value greater than 1 is selected. Another criterion is to select the number of factors that are above the curve break in the scree plot. If the number of factors is selected, it is necessary to find out which items belong to which factor. This can be done based on the calculation of factor loads, which are correlations between the factor and the relevant variable. The greater this correlation, the more the factor is saturated by this variable. To prevent factor loads from being strong for more than one factor, the socalled factor rotation (varimax method) is used. Otherwise, we would not know which factor to include the given variable. Factor analysis thus divides the investigated variables into a given number of factors. Besides, factor analysis creates new variables that can be used for further calculations and modelling. In the case of our research for the above- mentioned multiple linear regression. (for more details see Mareš, et al., 2015; Pallant, 2010).

The level of significance was set at a $p$-value of 0.1 . This level was set about the rather lower sample size and it is following the standard level used in other research (Schumm, et al. 2013).

\section{Conceptual Model}

The model includes the relationship between financial performance - profitability (subjectively determined concerning the previous period) and selected factors Customer satisfaction management, which could have an impact on the performance. Factors are created as constructs, ie. that they are composed of specific quantities (activities or processes that take place in the company), which form these factors and which were determined using individual questions of the questionnaire. See Figure 1 for details.
Financial Performance

\begin{tabular}{|c|c|c|}
\hline Subjective financial performance & \multicolumn{1}{|c|}{\begin{tabular}{|c|} 
Innovarion management in the company \\
\hline $\begin{array}{c}\text { Profitability compared } \\
\text { to the previous period }\end{array}$
\end{tabular}} & \begin{tabular}{|c|c|} 
Bnowledge management in the company \\
(from the customer)
\end{tabular} \\
\hline & & Determining customer satisfaction \\
\hline
\end{tabular}

Figure 1: Initial conceptual model of the relationship between financial performance and customer satisfaction performance

Innovation management was focused on the sources of ideas for innovation, to find connections with other researched factories. The quantities were therefore examined:

- customers (in line with Goldsmith, Flynn, Goldsmith, 2003),

- competitors (according to Flynn et al, 2003),

- $\quad$ suppliers (in line with Wagner and Bode, 2014),

- the company's internal resources (following $\mathrm{Gu}, \mathrm{Q}$., Jiang, W., \& Wang, G. G. (2016).

The four questions in the questionnaire answer these four variables, with the wording of the question as follows: "Where do the sources of ideas for improving or innovating products/processes come from?" The question is rated on a standard scale. As part of the company's knowledge management, these eleven variables were examined, which are also already represented by the relevant questions, resp. statements:

- knowledge management is part of the company's strategy,

- knowledge management is consciously and planned integrated into all processes in the company,

- the knowledge needed to determine the quality of products is acquired through the sharing of knowledge with customers,

- information system in our company helps to acquire, categorize, sort and search for knowledge and ideas for continuous improvement,

- thanks to the sharing of information and knowledge, we often come up with new ideas that can be used for continuous improvement,

- knowledge management leads to the provision of perfect product information to end customers,

- knowledge management in our company is aimed at minimizing process errors and minimizing backflows and waste,

- customer feedback regarding dissatisfaction is shared effectively by employees involved in product development and quality management,

- backflow information is an important input for product / process innovation / improvement,

- the sharing of information and knowledge from the feedback regarding customer dissatisfaction across the company is formalized in uniform and described processes,

- $\quad$ lease evaluate the knowledge about the satisfaction of your customers in your company.

The first ten quantities are determined by questions on the Likert scale, ie. in the form of agreement or disagreement with the said statement, which represents the relevant quantity. These ten variables were inspired by a comprehensive questionnaire and research questions from Abualoush et al. (2018). The last quantity is determined by the relevant question evaluated on a standard scale. The question was inspired by the research of Rollins, Halinen, (2005) and represents a link between knowledge management and customer satisfaction. As part of customer backflow management, the company's efforts to obtain information from the customer that could be used to increase customer 
satisfaction were examined. In constructing the factor, we proceeded from the statement that the most common reason for increasing profitability in the case of reverse flow management may be an increase in customer satisfaction (Petersen, Kumar, 2010). Within this factor, three quantities were examined, which are again presented here in the form of questions, resp. claim:

- we intensively collect information from our distributors on customer satisfaction,

- we work closely with customers to develop new products,

- we work very intensively with customers to know their wishes and needs.

The questions aimed at determining the above quantities were constructed in the form of an appropriate statement and evaluated on a standard scale. The questions are based on research by Zhang, et al. (2006). The survey of both customer satisfaction and dissatisfaction was also examined. The factor of customer satisfaction survey was focused primarily on the use of various tools and methods in the company and contains three quantities, respectively. claim:

- methods and tools for determining customer satisfaction are used in the work of several departments, departments or job positions,

- to ensure customer satisfaction, we use various methods of determining their needs and wishes at the stage of product design,

- we monitor customer satisfaction on an ongoing basis.

The questions aimed at determining the above quantities were constructed in the form of an appropriate statement and evaluated on a standard scale. All questions were inspired by the research of Morgan, Anderson, Mittal (2005), the second question by the research of Mehra, Ranganathan (2008), the third question by even more recent research by Mittal, Frennea (2010). The second factor was focused on determining customer dissatisfaction, respectively. to link information about dissatisfaction and to address possible customer dissatisfaction. This factor contains two quantities, resp. question and statement:

- what is the degree of internal integration and coordination (in the sense of interconnection through information, the interconnection of processes, functions) in your company regarding the solution of

\section{dissatisfaction,}

- determining the satisfaction of our customers brings us exactly the information we need.

The questions aimed at determining the above quantities were constructed in the form of an appropriate statement and evaluated on a standard scale. The first question was inspired by the Zaire research (2000), the second by the Artis research (2004).

\section{Research Sample}

Companies based in the Czech Republic were included in the sample. Data were collected using questionnaires. Data were obtained from a total of 278 businesses, 11 of which were then excluded as they make up the organizational portion (and thus only a part) of a business. From the remaining businesses, only 176 financial statements were obtainable, from which financial indicators of 113 businesses could be collected. These 113 businesses make up the research sample.

The enterprises were selected using stratified sampling that guaranteed sufficient representation of industry sectors (manufacturing vs services) and company size (small, middle and large companies). The aim was to have a diverse sample in these two parameters (industry affiliation and size) as the research problem focused on companies' performance, not the attributes mentioned above. The ambition was to achieve such sample structure (the proportions among strata) that corresponds to the structure of companies in the Czech economy both terms of industry and size. However, concerning the personal capacity and especially the financial constraints of the research grant, the research sample does not represent the industry and size structure well. We omit weighting the sample as this procedure wouldn't help in achieving the research goal. About the most frequent representation of medium-sized companies in the field of manufacturing, the results can be related to this group of companies.

The characteristics of the examined companies were performed concerning their subjective financial performance (using the profitability indicator in comparison with the previous period). The characteristics of enterprises by size (based on the number of employees) are given in Table 1.

\begin{tabular}{|l|l|l|l|l|l|l|}
\hline \multicolumn{2}{|c|}{} & $\begin{array}{l}\text { Micro- } \\
\text { enterprise } \\
(<\mathbf{1 0})\end{array}$ & $\begin{array}{l}\text { Small } \\
\text { enterprise } \\
(<\mathbf{5 0})\end{array}$ & $\begin{array}{l}\text { Medium-sized } \\
\text { enterprise (<250) }\end{array}$ & $\begin{array}{l}\text { Large } \\
\text { enterprise } \\
(>=250)\end{array}$ & Total \\
\hline $\begin{array}{l}\text { Subject. } \\
\text { profitability } \\
\text { past } \\
\text { comparison }\end{array}$ & below median & $\begin{array}{l}19 \\
13.4 \%\end{array}$ & $28.4 \%$ & 24 & 15 & 67 \\
\cline { 2 - 7 } & above median & 5 & 12 & $12.8 \%$ & $22.4 \%$ & $100 \%$ \\
\hline Total & $10.9 \%$ & $26.1 \%$ & $26.1 \%$ & 17 & 46 \\
& absolutely & 14 & $31.0 \%$ & $100 \%$ \\
\hline
\end{tabular}

Table 1: Size of enterprises by number of employees and by the subjective performance with the indication of absolute and relative frequencies

The table shows that medium-sized enterprises predominate in the sample, while the share of small and large enterprises is almost identical. In terms of the subjective financial performance indicator, less efficient companies (below the median) predominated in the sample, mainly due to micro, small and medium-sized enterprises.

The enterprises examined come from all economic sectors, with the secondary and tertiary sectors being represented almost equally, while the primary sector was represented by only two enterprises. The companies were of all sizes, with medium size of 60 employees. A quarter of the sample consisted of branches of multinational companies.

The respondents were managers of companies in positions that allowed them to answer questions in a qualified manner, ie they were mainly managers in top positions. Businesses were acquired through a combination of direct contact and mediated contacts. The questionnaire in online and printed form was used as a technique of data collection. 


\section{GENERAL MANAGEMENT}

\section{Results}

When modelling partial quantities within the above factors, first it is necessary to select these quantities, resp. verify that the factor constitutes. Factor analysis was used for selection, the results of which are shown in Table 2 . When examining variants of distribution of the investigated group of quantities within the modelled factors, the division into five factors proved to be the most suitable, which corresponds to the number of factors in the model shown in Figure 2.

\begin{tabular}{|c|c|}
\hline Factor & Component \\
\hline $\begin{array}{l}\text { Knowledge management statements - knowledge management in our company } \\
\text { is aimed at minimizing errors in processes and minimizing backflows and waste }\end{array}$ & 0.819 \\
\hline $\begin{array}{l}\text { Statements knowledge management - knowledge management is part of a } \\
\text { business strategy }\end{array}$ & 0.813 \\
\hline $\begin{array}{l}\text { Statements knowledge management - knowledge management is consciously } \\
\text { and systematically integrated into all processes in the company }\end{array}$ & 0.786 \\
\hline $\begin{array}{l}\text { Knowledge Management Statements - Customer feedback regarding } \\
\text { dissatisfaction is shared effectively by employees involved in product } \\
\text { development and quality management }\end{array}$ & 0.779 \\
\hline $\begin{array}{l}\text { Knowledge Management Statements - Knowledge management leads to the } \\
\text { provision of perfect product information to end customers }\end{array}$ & 0.776 \\
\hline $\begin{array}{l}\text { Knowledge Management Statements - Knowledge needed to determine the } \\
\text { quality of products is acquired through the sharing of knowledge with customers }\end{array}$ & 0.743 \\
\hline $\begin{array}{l}\text { Knowledge Management Statements - Sharing information and knowledge from } \\
\text { the feedback regarding customer dissatisfaction across the company is } \\
\text { formalized in individual and described processes }\end{array}$ & 0.743 \\
\hline $\begin{array}{l}\text { Knowledge Management Statements - Backflow information is an important } \\
\text { input for product / process innovation / improvement }\end{array}$ & 0.732 \\
\hline $\begin{array}{l}\text { Statements knowledge management - information system in our company helps } \\
\text { to acquire, categorize, sort and search for knowledge and ideas for continuous } \\
\text { improvement }\end{array}$ & 0.683 \\
\hline $\begin{array}{l}\text { Knowledge management statements - thanks to the sharing of information and } \\
\text { knowledge, we often come up with new ideas that can be used for continuous } \\
\text { improvement }\end{array}$ & 0.640 \\
\hline $\begin{array}{l}\text { What is the degree of internal integration and coordination (in the sense of } \\
\text { interconnection through information, the interconnection of processes, functions) } \\
\text { in your company regarding the solution of dissatisfaction }\end{array}$ & 0.568 \\
\hline Sources of innovation - customers & 0.785 \\
\hline $\begin{array}{l}\text { Satisfaction Survey - Satisfaction of our customers gives us exactly the } \\
\text { information we need }\end{array}$ & 0.785 \\
\hline $\begin{array}{l}\text { Please evaluate the knowledge about the satisfaction of your customers in your } \\
\text { company }\end{array}$ & 0.642 \\
\hline $\begin{array}{l}\text { Statements of minimizing backflows - We work very intensively with customers } \\
\text { to know their wishes and needs }\end{array}$ & 0.497 \\
\hline Sources of innovation - internal resources of the company & 0.770 \\
\hline $\begin{array}{l}\text { Satisfaction Statements - To ensure customer satisfaction, I use various } \\
\text { methods of determining their needs and desires at the stage of product design }\end{array}$ & 0.581 \\
\hline $\begin{array}{l}\text { Satisfaction statements - We determine customer satisfaction on an ongoing } \\
\text { basis }\end{array}$ & 0.586 \\
\hline $\begin{array}{l}\text { Satisfaction statements - Methods and tools for determining customer } \\
\text { satisfaction are used in the work of several departments, departments or job } \\
\text { positions }\end{array}$ & 0.557 \\
\hline $\begin{array}{l}\text { Backflow Minimization Statements - We intensively collect information from our } \\
\text { distributors about customer satisfaction }\end{array}$ & 0.844 \\
\hline $\begin{array}{l}\text { Backflow minimization statements - We work closely with customers to develop } \\
\text { new products }\end{array}$ & 0.668 \\
\hline Sources of innovation - competitors & 0.851 \\
\hline Sources of innovation - suppliers & 0.737 \\
\hline
\end{tabular}

Table 2: Factor analysis of the investigated partial quantities of relevant factors

The results of the factor analysis show that the 23 examined partial quantities forming 5 factors were divided equally into 5 factors (11 quantities for the first factor, 4 and 4 quantities for the other two factories and finally 2 and 2 quantities for the last two factors). Interestingly, the factors created in this way do not completely correspond to the factors conceived in the conceptual model (for more details, see Figure 1). The most comprehensive group with 11 sub- variables is the factor Knowledge Management in the company, were compared to the model, the value Evaluation of knowledge of customer satisfaction is replaced by the quantity Degree of integration and coordination in the company related to solving customer dissatisfaction. The second factor, which contains 4 sub-variables, is intertwined with four factors (Innovation Management, Customer Dissatisfaction Detection, Enterprise Knowledge Management 


\section{GENERAL MANAGEMENT}

and Reverse Flow Management). It is obvious that this factor is most associated with customers, their dissatisfaction, who in this sense are a source of information and innovation, which is related to knowledge of customer satisfaction and minimization of backflows from the customer. In this regard, the importance of innovation, knowledge and quality in conjunction with a (dissatisfied) customer is shown. In the case of this factor, the customer thus forms a bolt of quantities from otherwise different factors. In essence, the customer can be considered a source (innovation, information and knowledge) in this regard, so this factor can be called the Customer as a source of innovation and knowledge.

The third factor contains 4 sub-variables, which form all three variables Customer satisfaction survey, which is supplemented by a source of innovation (internal). It is obvious that this factor is very closely connected with the functioning of the company, with its management systems and their settings and methods of use, as well as targeting customer satisfaction. This shows the importance of the company's internal resources, in terms of the correct setting of the methods and tools used, ie. their use across the company to ensure customer satisfaction (as soon as possible, ie already in the pre-production stage) and their continuous (frequent) use. The factor is thus associated with customer satisfaction management and can be more accurately called the Internal Customer Satisfaction Management Support System.

The fourth factor contains 2 sub-variables that are part of the Backflow Control factor, so in this case, only one variable was removed from the factor. The situation is similar for the last, fifth factor, which consists of the quantities of the Innovation Management factor, by which one quantity was also taken away. The analysis shows that this factor consists exclusively of external sources of innovation, so it can be (more precisely) called Management of external sources of innovation. The results show that in creating the conceptual model, four out of five factors were created correctly. All factories underwent some changes, but only in the case of one factor were these changes significant. These five partial factors were then modelled in regression analysis and their impact on the performance (profitability) of the company was determined. The results are shown below in tables.

\begin{tabular}{|l|l|l|l|l|}
\hline Model & R & R Square & Adjusted R Square & Std. Error of the Estimate \\
\hline 1 & 0.4473 & 0.199 & 0.156 & 1.151 \\
\hline
\end{tabular}

Table 3: Model Summary

Note: Predictors: (Constant), REGR factor score 5 for analysis 1, REGR factor score 3 for analysis 1, REGR factor score 2 for analysis 1, REGR factor score 4 for analysis 1 , REGR factor score 1 for analysis 1

The results show that the correlation coefficient (multiple correlation coefficient between the measured and expected value of the dependent variable) of the model is $44.7 \%$, which indicates a medium dependence (De Vaus, 2002). data analysis. sage. Or another source). It can be stated that the observed dependence of the investigated factors is statistically significant. Below are the results of the regression function with the appropriate tests. However, the coefficient of determination is relatively low $(19.9 \%)$, so it is clear that despite the proven dependence of the examined factors on the performance of the company, the explanatory power of the model is lower. It can be concluded that there are other factors (and sub-variables) that affect the performance of the company.

\begin{tabular}{|l|l|l|}
\hline Model & $\mathrm{F}$ & Sig. \\
\hline Regression & 4.584 & $0.001 \mathrm{a}$ \\
\hline
\end{tabular}

Table 4: ANOVA

a Predictors (Constant), REGR factor score 5 for analysis 1, REGR factor score 3 for analysis 1, REGR factor score 2 for analysis 1, REGR factor score 4 for analysis 1 , REGR factor score 1 for analysis 1

\begin{tabular}{|l|l|l|l|l|l|}
\hline \multirow{2}{*}{ Model } & \multicolumn{2}{|l|}{$\begin{array}{l}\text { Unstandardized } \\
\text { Coefficients }\end{array}$} & $\begin{array}{l}\text { Standardized } \\
\text { Coefficients }\end{array}$ & t & Sig. \\
\cline { 2 - 6 } & $\mathbf{B}$ & $\begin{array}{l}\text { Std. } \\
\text { Error }\end{array}$ & Beta & & \\
\hline (Constant) & 4.538 & 0.116 & - & 39.013 & 0.000 \\
\hline REGR factor score 1 for analysis 1 & 0.145 & 0.117 & 0.115 & 1.236 & 0.220 \\
\hline REGR factor score 2 for analysis 1 & 0.294 & 0.117 & 0.235 & 2.521 & 0.013 \\
\hline REGR factor score 3 for analysis 1 & 0.227 & 0.117 & 0.182 & 1.947 & 0.055 \\
\hline REGR factor score 4 for analysis 1 & 0.340 & 0.117 & 0.271 & 2.909 & 0.005 \\
\hline REGR factor score 5 for analysis 1 & 0.190 & 0.116 & -0.152 & -1.630 & 0.107 \\
\hline
\end{tabular}

Table 5: Coefficients

Based on the research results, the resulting model can be constructed, which is shown in Figure 2 . This model shows the relationship of five constructed factors (enterprise knowledge management, customer as a source of innovation and knowledge, internal customer satisfaction management support system, reverse flow management and external sources of innovation) and within them 23 variables (11, 4, 4, 2, 2 for the above factors) to the performance (subjective profitability) of the company. Statistically significant factors are marked in bold (customer as a source of innovation and knowledge, an internal support system for customer satisfaction management and reverse flow management). 


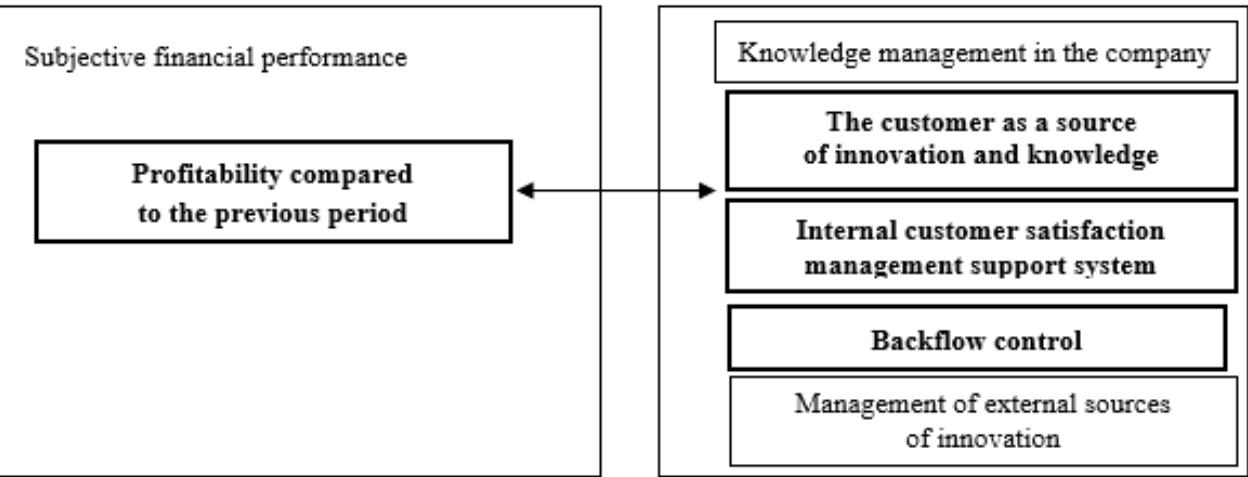

Figure 2: The resulting model of the relationship between financial performance and customer satisfaction management

\section{Discussion}

The analysis of quantities (especially in the form of activities and processes), which were identified as components of the analyzed factors of the Customer satisfaction management system, showed that their actual assignment to individual factors based on the results of factor analysis is somewhat different from the conceptual model (see Figure 1). The connection between research activities and processes in our research is therefore somewhat different from the research already carried out, from which we drew during a literature search. The question is whether this is due to the specific situation of the examined Czech companies or the situation on the market (the research was carried out at a time of high, global economic situation) or other reasons. However, due to the influence of these variables (activities and processes) on the financial performance of companies, it is clear that the correct organization of processes has a positive effect on this performance and, conversely, their incorrect systematization is a source of inefficient operation of the company, which results in reduced profitability.

It was found that all investigated variables affect (subjective and financial) performance, although there was a partial regrouping of these variables within the investigated factors. Probably the most striking is the factor of innovation management in the company, which split into two factors: Management of external sources of innovation and Customer as a source of innovation and knowledge. It follows, among other things, that the processes and activities associated with innovation are located in different places in the company and are part of several seemingly diverse activities. This in turn worsens the overview of these activities and the possibilities of their effective management (in terms of minimum costs). However, all factors have undergone certain changes, ie. that for all factors there were shifts in quantities in terms of activities and processes. The analysis confirmed the dominant position of the customer and the correctness of the concept of customer satisfaction management, as written by Piskóti \& Nagy (2009), as all examined factors and sub-variables are aimed at ensuring the planned customer satisfaction of the company.

However, concerning the statistical significance of the results, it is necessary to reduce the model from five examined factors to three. It is very interesting that among the statistically significant factors influencing the performance of the company is also the new factor Customer as a source of innovation and knowledge. Within this factor, the importance of setting up and especially managing activities related to obtaining information from the customer, ensuring the correct information about the customer and their transformation into knowledge about the customer is shown. Our research in this regard is consistent with the findings of Rollins, Halinen (2005). Besides, linking these activities to a separate process proves to be key to the company's financial performance (profitability). The influence of sources of innovation on financial performance has been demonstrated by Zahra, Das (1993), and our research expands the sense that it is not only the source of innovation itself (as part of the process) but the whole process that is related to it. mentioned above.

The most important factor that most influences the company's financial performance is Backflow Management. A closer look at the magnitudes of the factor makes it clear that these are mainly intangible (information) flows as understood by, for example, Krumwiede, Sheu (2002), which relate to the intensive acquisition of customer information from distributors and the use of information from customers in developing new products (compare with Kindström, et al., 2014). This is typical of companies that produce products that they distribute through intermediaries. Gaining and using information from customers is thus more complicated than in the case of providing services, but it is all the more important to set up an effective (correct) system. A well-configured customer feedback system can save costs associated with returning products that customers are dissatisfied with by creating a product according to the customer's requirements. Besides, the sub-variables (activities) of the Backflow Management factor suitably complement the process of knowledge and innovation management within the process of the abovementioned factor.

The last factor that forms Customer satisfaction management in our (partial) research is a factor called the Internal Customer Satisfaction Management Support System because it is mostly focused on internal variables (activities and processes), although in this case they are of course focused on the customer. Among the important variables that affect the financial performance of the company are the internal resources of the company. The research shows that these sources include the use of various (ie more than one) methods of determining customer needs, already in the design of the product. This quantity (activity) is thus directly linked to the quantity of the use of information from customers in the development of new products of the Backflow Management factor. It is also important to use these methods in the company together (in the sense of several, ideally all, departments of the company). Another important factor is the frequency of customer satisfaction surveys, and research shows that customer satisfaction can be assessed on an ongoing basis, as specified by the research of Casas-Arce et 
al. (2017) and So et al. (2013). It can be concluded that information about customer satisfaction can be used in the company to increase its financial performance. To increase financial performance, it is difficult to have the right information and work with it within the company (whether about the various methods by which it will be processed, sharing within the company and using them to increase knowledge and create innovation). Through information, the individual factors of customer satisfaction management are connected and information thus appears to be a more difficult and basic element of successful customer satisfaction management, ie management that increases the financial performance of the company.

\section{Conclusions}

The uniqueness of research lies in the orientation to information knowledge and work with them, ie. where to obtain information and knowledge (whether outside the company or in the company), which information to obtain and how to use it subsequently (turn it into the right information) in order to increase customer satisfaction and consequently the financial performance of the company. Therefore, the research is focused inside the company, on managers. Other research focused on customer satisfaction management is primarily customer-oriented and focuses on the use of customer information (see eg Piskóti \& Nagy, 2009) or focuses on the interconnection of customer satisfaction and internal business processes, but without proving (statistically significant relationships ( see, e.g., Munari et al., 2013) Our approach is not only more complex but also more convincing.

The connection, resp. Demonstrating the relationship between customer satisfaction management and business financial performance. The relationship between customer satisfaction and (business) performance was examined in the literature (Eklof, Podkorytova, Malova, 2018; Jyoti, Kour, Sharma, 2017; Mittal, Frennea (2010), but the relationship between customer satisfaction management (with emphasis on work) was not examined. Research (Piskóti \& Nagy, 2009; Munari et al., 2013) focused on customer satisfaction management addresses the relationship with customer value (not with the value or performance of the company).

The creation of customer satisfaction management factors and their connection to business performance is also original. Not surprisingly, Customer is a source of innovation and knowledge (cf. Darroch 2005; Van der Spek, Carter, 2005), although the combination of source of innovation and knowledge in a single factor may be somewhat surprising, as factors tend to be separate by default. , especially in the context of business performance evaluation (cf. Abualoush et al., 2018, Neely, Hii, 1998, Alrubaiee et al., 2015). Interesting and original is their connection with Back flow control and Internal Customer Satisfaction Management Support System. Back flow control is focused on gathering information about customer satisfaction and developing a new product in cooperation with the customer, thus complementing the previous factor. These two factors therefore lead the company to obtain the right information from the customer and use them to innovate the product, respectively. development of a new product (with an emphasis on fulfilling the wishes of customers). Internal Customer Satisfaction Management Support The system is focused on internal (corporate) sources of innovation, on methods aimed at determining customer satisfaction and their expansion in the company and especially on their ongoing use. The first two factors connect the company and the customer through the flow of information and knowledge and work with them, the third factor is focused on the internal functioning of the company, respectively. certain methods, their dissemination, continuous collection of information and their flow in the company.

The above factors and relationships have so far been examined unsystematically, respectively. in other or only partial contexts. For example, the effectiveness of measuring customer satisfaction, including the frequency of measurements, was examined (Morgan et al, 2005), and it was found that measuring customer satisfaction should be continuous and using multiple methods (Grigoroudis and Siskos, 2009). Feedback was also investigated, including its frequency (Casas - Arce et al., 2017, So, et al., 2013), the use of feedback flows as a source of feedback (Russo, Cardinalli, 2012) or as a source of innovation (Un, Cuero -Cazurra, 2007).

The limits of research include focusing on companies within the Czech Republic, which may not be similar to companies in other countries, although the Czech Republic's involvement in EU structures and more than thirty years of economic transformation, the situation of Czech and European companies can be considered (at least in the European context). comparable. A more significant limitation of the research is the partial focus of the research, which was caused by a smaller research sample, which did not allow to analyze together a larger number of quantities and factors. Further research should be focused more extensively, especially concerning the number of surveyed companies so that it is possible to include in Customer satisfaction management other factors and variables (activities and processes) that the company performs and which are related to the customer, resp. which would be to should bind the customer. Research is also offered to be conducted in other countries, whether the EU or the world.

\section{References}

[1] Abualoush, S., Masa'deh, R., Bataineh, K., \& Alrowwad, A (2018). The Role of Knowledge Management Process and Intellectual Capital as Intermediary Variables between Knowledge Management Infrastructure and Organization Performance. Interdisciplinary Journal of Information, Knowledge, and Management, 13, 279-309. doi:10.28945/4088

[2] Alrubaiee, L., Alzubi, H. M., Hanandeh, R., Ali, R. A., 2015, Investigating the relationship between knowledge management processes and organizational performance the mediating effect of organizational innovation. International Review of Management and Business Research, 4(4), 989-1009.

[3] Andreeva, T., \& Kianto, A. (2012). Does knowledge management really matter? Linking knowledge management practices, competitiveness and economic performance. Journal of Knowledge Management, 16(4), 617-636. doi:10.1108/13673271211246185

[4] Artis, A. B. (2004). A taxonomy of customer dissatisfactionrelated coping tactics based on dissatisfaction-related goals.

[5] Atalay, M., Anafarta, N., \& Sarvan, F. (2013). The Relationship between Innovation and Firm Performance: An Empirical Evidence from Turkish Automotive Supplier Industry. Procedia Social and Behavioral Sciences, 75, 226-235 doi:10.1016/j.sbspro.2013.04.026.

[6] Berraies, S., \& Hamouda, M. (2018). Customer empowerment and firms' performance. International Journal of Bank Marketing, 36(2), 336-356. doi:10.1108/ijbm-10-2016-0150

[7] Butler, Y. (2000). Knowledge management-if only you knew what you knew. The Australian Library Journal, 49(1), 31-43. doi:10.1080/00049670.2000.10755905

[8] Calantone, R. J., Cavusgil, S. T., \& Zhao, Y. (2002). Learning orientation, firm innovation capability, and firm performance. Industrial Marketing Management, 31(6), 515-524. doi:10.1016/s0019-8501(01)00203-6

[9] CASAS-ARCE, P., LOURENÇO, S. M., \& MARTíNEZ-JEREZ, 
F. A. (2017). The Performance Effect of Feedback Frequency and Detail: Evidence from a Field Experiment in Customer Satisfaction. Journal of Accounting Research, 55(5), 1051-1088. doi:10.1111/1475-679x.12184

[10] Cassel, C., \& Eklöf, J. A. (2001). Modelling customer satisfaction and loyalty on aggregate levels: Experience from the ECSI pilot study. Total Quality Management, 12(7-8), 834-841. doi:10.1080/09544120100000004

[11] Cristian, S., Monica, L., 2017, Measuring performance in organizations from multi-dimensional perspective. Annals of the University of TâRgu Jiu, Economy Series, 4, 217-223.

[12] Damanpour, F. (1991). Organizational Innovation: A MetaAnalysis Of Effects Of Determinants and Moderators. Academy of Management Journal, 34(3), 555-590. doi:10.5465/256406

[13] Darroch, J. (2005). Knowledge management, innovation and firm performance. Journal of Knowledge Management, 9(3), 101-115. doi:10.1108/13673270510602809

[14] Dasgupta, M., \& Gupta, R. K. (2009). Innovation in Organizations. Global Business Review, 10(2), 203-224. doi:10.1177/097215090901000205

[15] Dawes, J., 1999, The relationship between subjective and objective company performance measures in market orientation research: further empirical evidence. Marketing BulletinDepartment of Marketing Massey University, 10, 65-75.

[16] De Brito, M. P., 2003, Managing reverse logistics or reversing logistics management, ERIM Ph.D. Series Research in Management, 35, Erasmus University Rotterdam.

[17] Deng, S., \& Dart, J. (1994). Measuring market orientation: A multi-factor, multi-item approach. Journal of Marketing Management, 10(8), 725-742. doi:10.1080/0267257x.1994.9964318

[18] Deshpandé, R., Farley, J. U., \& Webster, F. E. (1993). Corporate Culture, Customer Orientation, and Innovativeness in Japanese Firms: A Quadrad Analysis. Journal of Marketing, 57(1), 23-37. doi:10.1177/002224299305700102

[19] Dess, G. G., Robinson Jr, R. B., 1984, Measuring organizational performance in the absence of objective measures: the case of the privately-held firm and conglomerate business unit. Strategic management journal, 5(3), 265-273.

[20] Drucker, P. F., 1992, Managing the Non-Profit Organization: Principles and Practices. New York: Collins.

[21] Drury, C. G. (2000). Global quality: Linking ergonomics and production. International Journal of Production Research, 38(17), 4007-4018. doi:10.1080/00207540050204876

[22] Eklof, J., Podkorytova, O., \& Malova, A. (2018). Linking customer satisfaction with financial performance: an empirical study of Scandinavian banks. Total Quality Management \& Business Excellence, 31(15-16), 1684-1702. doi:10.1080/14783363.2018.1504621

[23] Fernández Quesada, I., 2003, The concept of reverse logistics: A review of literature. In Annual Conference for Nordic Researchers in Logistics (NOFOMA 03), 1-15.

[24] Delgado Ferraz, F. A., \& Gallardo-Vázquez, D. (2016). Measurement tool to assess the relationship between corporate social responsibility, training practices and business performance. Journal of Cleaner Production, 129, 659-672. doi:10.1016/j.jclepro.2016.03.104

[25] FLYNN, M., DOOLEY, L., O'SULLIVAN, D., \& CORMICAN, K. (2003). IDEA MANAGEMENT FOR ORGANISATIONAL INNOVATION. International Journal of Innovation Management, 07(04), 417-442. doi:10.1142/s1363919603000878

[26] Fornell, C., Johnson, M. D., Anderson, E. W., Cha, J., \& Bryant, B. E. (1996). The American Customer Satisfaction Index: Nature, Purpose, and Findings. Journal of Marketing, 60(4), 718. doi:10.1177/002224299606000403

[27] Fundin, A. P., \& Bergman, B. L. S. (2003). Exploring the customer feedback process. Measuring Business Excellence, 7(2), 55-65. doi:10.1108/13683040310477995

[28] Ghobadian, A., \& Speller, S. (1994). Gurus of quality: a framework for comparison. Total Quality Management, 5(3), 5370. doi:10.1080/09544129400000025
[29] Gholami, M. H., Asli, M. N., Nazari-Shirkouhi, S., Noruzy, A., 2013, Investigating the influence of knowledge management practices on organizational performance: an empirical study. Acta Polytechnica Hungarica, 10(2), 205-216.

[30] Gilly, M. C., 1979, Complaining consumers and the concept of expectations, in Hunt, H.K. and Day, R.L. (Eds), Refining Concepts and Measures of Consumer Satisfaction and Complaining Behavior, Indiana University, Bloomington, IN, 3543

[31] Giuntini, R, Andel, T., 1995, Advance with Reverse Logistics: Part 1. Transportation \& Distribution, 36(2), 73-75.

[32] Goldsmith, R. E., Flynn, L. R., \& Goldsmith, E. B. (2003). Innovative Consumers and Market Mavens. Journal of Marketing Theory and Practice, 11(4), 54-65. doi:10.1080/10696679.2003.11658508

[33] Grigoroudis, E., Siskos, Y., 2009, Customer satisfaction evaluation: Methods for measuring and implementing service quality, 139, Springer Science \& Business Media.

[34] Gu, Q., Jiang, W., \& Wang, G. G. (2016). Effects of external and internal sources on innovation performance in Chinese high-tech SMEs: A resource-based perspective. Journal of Engineering and Technology Management, 40, 76-86. doi:10.1016/j.jengtecman.2016.04.003

[35] GUNASEKARAN, A., WILLIAMS, H., \& MCGAUGHEY, R. (2005). Performance measurement and costing system in new enterprise. Technovation, 25(5), 523-533. doi:10.1016/s01664972(03)00176-7

[36] Guo, C., Kumar, A., \& Jiraporn, P. (2004). Customer satisfaction and profitability: is there a lagged effect? Journal of Strategic Marketing, 12(3), 129-144. doi:10.1080/0965254042000262878

[37] Gupta, M., \& Galloway, K. (2003). Activity-based costing/management and its implications for operations management. Technovation, 23(2), 131-138. doi:10.1016/s0166-4972(01)00093-1

[38] Hammes, G., De Souza, E. D., Taboada Rodriguez, C. M., Rojas Millan, R. H., \& Mojica Herazo, J. C. (2020). Evaluation of the reverse logistics performance in civil construction. Journal of Cleaner Production, 248, 119212 doi:10.1016/j.jclepro.2019.119212

[39] Hult, G. T. M., Hurley, R. F., \& Knight, G. A. (2004). Innovativeness: Its antecedents and impact on business performance. Industrial Marketing Management, 33(5), 429-438. doi:10.1016/j.indmarman.2003.08.015

[40] Chen, C.-C., \& Cheng, W.-Y. (2006). Customer-focused and product-line-based manufacturing performance measurement. The International Journal of Advanced Manufacturing Technology, 34(11-12), 1236-1245. doi:10.1007/s00170-0060686-0

[41] Cho, H., Pucik, V., 2005, Relationship between innovativeness, quality, growth, profitability, and market value. Strategic Management Journal, 26(6), 555-570.

[42] Jiménez-Jiménez, D., \& Sanz-Valle, R. (2011). Innovation, organizational learning, and performance. Journal of Business Research, 64(4), 408-417. doi:10.1016/j.jbusres.2010.09.010

[43] Johannessen, J.-A. (2008). Organisational innovation as part of knowledge management. International Journal of Information Management, 28(5), 403-412. doi:10.1016/j.ijinfomgt.2008.04.007

[44] Jyoti, J., Kour, S., \& Sharma, J. (2017). Impact of total quality services on financial performance: role of service profit chain. Total Quality Management \& Business Excellence, 28(7-8), 897-929. doi:10.1080/14783363.2016.1274649

[45] Kaplan, R. S. \& Norton, D. P., 2001, The strategy-focused organization: How balanced scorecard companies thrive in the new business environment. Harvard Business Press.

[46] Carbonell, P., \& Rodriguez-Escudero, A.-I. (2014). Antecedents and consequences of using information from customers involved in new service development. Journal of Business \& Industrial Marketing, 29(2), 112-122. doi:10.1108/jbim-04-2012-0071

[47] Kobylanski, A., Pawlowska, B., Strychalska-Rudzewicz, A., 2011, The role of customer satisfaction in the quality 
management systems: a crosscultural study. International Journal of Management and Marketing Research, 4(3), 57-74.

[48] Kopicki, R. R. J., Berg, M. J., Legg, L., Dasappa, V., Maggioni, C., 1993, Reuse and recycling: reverse logistics opportunities. Council of Logistics Management, Oak Brook, IL.

[49] Kroon, L., \& Vrijens, G. (1995). Returnable containers: an example of reverse logistics. International Journal of Physical Distribution \& Logistics Management, 25(2), 56-68. doi:10.1108/09600039510083934

[50] Krumwiede, D. W., \& Sheu, C. (2002). A model for reverse logistics entry by third-party providers. Omega, 30(5), 325-333. doi:10.1016/s0305-0483(02)00049-x

[51] Kuik, S. S., Nagalingam, S. V., Amer, Y., 2011, A framework of product recovery to improve sustainability in manufacturing. Lecture Notes in Information Technology Vols, 1(2), 232-235.

[52] Kumar, S., Dieveney, E., \& Dieveney, A. (2009). Reverse logistic process control measures for the pharmaceutical industry supply chain. International Journal of Productivity and Performance Management, $58(2)$,

188-204. doi:10.1108/17410400910928761

[53] Larsen, S. B., Masi, D., Feibert, D. C., \& Jacobsen, P. (2018). How the reverse supply chain impacts the firm's financial performance. International Journal of Physical Distribution \& Logistics Management, 48(3), 284-307. doi:10.1108/ijpdlm-012017-0031

[54] Mareš, P., Rabušic, L., Soukup, P., 2015, Analýza sociálněvědních dat (nejen) v SPSS. Masarykova univerzita.

[55] Mehra, S., Ranganathan, S., 2008, Implementing total quality management with a focus on enhancing customer satisfaction. International Journal of Quality \& Reliability Management, 25(9), 913-927.

[56] Minnema, A., Bijmolt, T. H. A., Gensler, S., \& Wiesel, T. (2016). To Keep or Not to Keep: Effects of Online Customer Reviews on Product Returns. Journal of Retailing, 92(3), 253-267. doi:10.1016/j.jretai.2016.03.001

[57] Mittal, V., Frennea, C., 2010, Customer satisfaction: a strategic review and guidelines for managers. MSI Fast Forward Series, Marketing Science Institute, Cambridge, MA.

[58] Mollenkopf, D. A., Frankel, R., \& Russo, I. (2010). Creating value through returns management: Exploring the marketingoperations interface. Journal of Operations Management, 29(5), 391-403. doi:10.1016/j.jom.2010.11.004

[59] Mollenkopf, D., Russo, I., \& Frankel, R. (2007). The returns management process in supply chain strategy. International Journal of Physical Distribution \& Logistics Management, 37(7), 568-592. doi:10.1108/09600030710776482

[60] Morgan, N. A., Anderson, E. W., \& Mittal, V. (2005). Understanding Firms' Customer Satisfaction Information Usage. Journal of Marketing, 69(3), 131-151. doi:10.1509/jmkg.69.3.131.66359

[61] Muffatto, M., Panizzolo, R., 1995, A process-based view for customer satisfaction. International Journal of Quality \& Reliability Management, 12(9),154-169.

[62] Munari, L., lelasi, F., \& Bajetta, L. (2013). Customer satisfaction management in Italian banks. Qualitative Research in Financial Markets, 5(2), 139-160. doi:10.1108/qrfm-11-2011-0028

[63] Munizu, M., Hamid, N., 2018, Mediation Effect of Innovation on the Relationship between Creativity with Business Performance at Furniture Industry in Indonesia. Quality-Access to Success, 19(165), 98-102

[64] Nabitz, U., Klazinga, N., Walburg, J. A. N., 2000, The EFQM excellence model: European and Dutch experiences with the EFQM approach in health care. International Journal for Quality in Health Care, 12(3), 191-202.

[65] Narver, J. C., Slater, S. F., 1990, The effect of a market orientation on business profitability. The Journal of marketing, 54(4), 20-35.

[66] Neely, A., \& Wilson, J. (1992). Measuring Product Goal Congruence: An Exploratory Case Study. International Journal of Operations \& Production Management, 12(4), 45-52. doi:10.1108/01443579210011589

[67] Neely, A., Hii, J., 1998, Innovation and business performance: a literature review. The Judge Institute of Management Studies, University of Cambridge, 0-65.

[68] Neely, A., Gregory, M. Platts, K., 2005, Performance measurement system design: A literature review and research agenda. International Journal of Operations and Production Management, 25(12), 1228-1263.

[69] Pakdil, F., Özkök, O., Dengiz, B., Kara, I., Selvi, N., \& Kargı, A. (2009). A systematic approach to reduce human and systemrelated errors causing customer dissatisfaction in a production environment. Total Quality Management \& Business Excellence, 20(1), 129-137. doi:10.1080/14783360802351728

[70] Pallant, J., 2020, SPSS survival manual: A step by step guide to data analysis using IBM SPSS. Routledge.

[71] Petersen, J. A., Kumar, V., 2010, Can product returns make you money?. MIT Sloan Management Review, 51(3), 85 - 89.

[72] Piskóti, I., Nagy, S., 2009, A new customer satisfaction management model (methodology and practice). EKONOMIKA IR VADYBA, 14

[73] Prajogo, D. I. (2006). The relationship between innovation and business performance-a comparative study between manufacturing and service firms. Knowledge and Process Management, 13(3), 218-225. doi:10.1002/kpm.259

[74] Prajogo, D. I., Sohal, A. S., 2004, Transitioning from total quality management to total innovation management. International journal of quality \& reliability management, 21(8), 861-875.

[75] Reichheld, F. F., Sasser, W. E., 1990, Zero defections: Quality comes to services. Harvard business review, 68(5), 105-111.

[76] Rollins, M., Halinen, A., 2005, Customer knowledge management competence: Towards a theoretical framework. In Proceedings of the 38th Annual Hawaii International Conference on System Sciences (240a-240a). IEEE.

[77] Rosenbusch, N., Brinckmann, J., \& Bausch, A. (2011). Is innovation always beneficial? A meta-analysis of the relationship between innovation and performance in SMEs. Journal of $\begin{array}{lll}\text { Business Venturing, 26(4), 441-457. } & \end{array}$ doi:10.1016/j.jbusvent.2009.12.002

[78] Rubera, G., \& Kirca, A. H. (2017). You gotta serve somebody: the effects of firm innovation on customer satisfaction and firm value. Journal of the Academy of Marketing Science, 45(5), 741-761. doi:10.1007/s11747-016-0512-7

[79] Russo, I., Cardinali, S., 2012, Product returns and customer value: a footware industry case. Modelling value, Physica-Verlag HD, 79-97.

[80] Sharma, B., Gadenne, D., 2008, An empirical investigation of the relationship between quality management factors and customer satisfaction, improved competitive position and overall business performance. Journal of Strategic Marketing, 16(4), 301-314.

[81] Schumm, W. R., Pratt, K. K., Hartenstein, J. L., Jenkins, B. A., \& Johnson, G. A. (2013). Determining statistical signifi cance (alpha) and reporting statistical trends: controversies, issues, and facts1. Comprehensive Psychology, 2(1), Article 10. doi:10.2466/03.cp.2.10

[82] So, Y., Lee, K., \& Oah, S. (2013). Relative Effects of Daily Feedback and Weekly Feedback on Customer Service Behavior at a Gas Station. Journal of Organizational Behavior Management, 33(2), 137-151. doi:10.1080/01608061.2013.785898

[83] Song, M., Droge, C., Hanvanich, S., \& Calantone, R. (2005). Marketing and technology resource complementarity: an analysis of their interaction effect in two environmental contexts. Strategic Management Journal, 26(3), 259-276. doi: $10.1002 / \mathrm{smj} .450$

[84] Stock, J. R., \& Mulki, J. P. (2009). PRODUCT RETURNS PROCESSING: AN EXAMINATION OF PRACTICES OF MANUFACTURERS, WHOLESALERS/DISTRIBUTORS, AND RETAILERS. Journal of Business Logistics, 30(1), 33-62. doi:10.1002/j.2158-1592.2009.tb00098.x

[85] Stock, J., Speh, T., Shear, H., 2006, Managing product returns 


\section{GENERAL MANAGEMENT}

for competitive advantage. MIT Sloan management review, 48(1), 57-62.

[86] Stone-Romero, E. F., Stone, D. L., Grewal, D., 1997, Development of a multidimensional measure of perceived product quality. Journal of quality management, 2(1), 87-111.

[87] Subramanian, A., Nilakanta, S., 1996, Organizational innovativeness: Exploring the relationship between organizational determinants of innovation, types of innovations, and measures of organizational performance. Omega, 24(6), 631-647.

[88] Sun, K.-A., \& Kim, D.-Y. (2013). Does customer satisfaction increase firm performance? An application of American Customer Satisfaction Index (ACSI). International Journal of Hospitality Management, 35, 68-77. doi:10.1016/j.ijhm.2013.05.008

[89] Sun, K. A., Kim, D. Y., 2013, Does customer satisfaction increase firm performance? An application of American Customer Satisfaction Index (ACSI). International Journal of Hospitality Management, 35, 68-77.

[90] Škapa, R., Klapalová, A., 2019, The Effectiveness of Reverse Logistics: The Empirical Test of Its Factors for Product Returns Reduction. Ekonomicky Casopis, 67(1), 86-104.

[91] Thierry, M., Salomon, M., Van Nunen, J., \& Van Wassenhove, L. (1995). Strategic Issues in Product Recovery Management. California Management Review, 37(2), 114-136. doi:10.2307/41165792

[92] Tosi, H. L., Werner, S., Katz, J. P., \& Gomez-Mejia, L. R. (2000). How Much Does Performance Matter? A Meta-Analysis of CEO Pay Studies. Journal of Management, 26(2), 301-339. doi:10.1177/014920630002600207

[93] Tse, D. K., \& Wilton, P. C. (1988). Models of Consumer Satisfaction Formation: An Extension. Journal of Marketing Research, 25(2), 204. doi:10.2307/3172652

[94] Un, C. A., \& Cuervo-Cazurra, A. (n.d.). Interactions with Customers for Innovation. Handbook of Research on Strategy and Foresight. doi:10.4337/9781848447271.00029

[95] Van der Spek, R., \& Carter, G. (2003). A Survey on Good Practices in Knowledge Management in European Companies. Knowledge Management, 191-206. doi:10.1007/978-3-54024778-4_9
[96] Veronica, D., 2017, The Necessity of Approaching the Enterprise Performance Concept through a Theoretical Fundamental System. Annals-Economy Series, 5, 63-69.

[97] Vij, S., Bedi, H. S. 2016, Are subjective business performance measures justified?. International Journal of Productivity and Performance Management, 65(5), 603-62.

[98] Wagner, S. M., \& Bode, C. (2013). Supplier relationship-specific investments and the role of safeguards for supplier innovation sharing. Journal of Operations Management, 32(3), 65-78. doi:10.1016/j.jom.2013.11.001

[99] WALL, T. D., MICHIE, J., PATTERSON, M., WOOD, S. J., SHEEHAN, M., CLEGG, C. W., \& WEST, M. (2004). ON THE VALIDITY OF SUBJECTIVE MEASURES OF COMPANY PERFORMANCE. Personnel Psychology, 57(1), 95-118. doi:10.1111/j.1744-6570.2004.tb02485.x

[100]ZAHRA, S. A., \& DAS, S. R. (2009). INNOVATION STRATEGY AND FINANCIAL PERFORMANCE IN MANUFACTURING COMPANIES: AN EMPIRICAL STUDY. Production and Operations Management, 2(1), 15-37. doi:10.1111/j.19375956.1993.tb00036.x

[101]Zairi, M., 2000, Managing customer satisfaction: a best practice perspective. The TQM magazine.

[102]Zand, J. D., Keramati, A., Shakouri, F., \& Noori, H. (2018). Assessing the impact of customer knowledge management on organizational performance. Knowledge and Process Management, 25(4), 268-278. doi:10.1002/kpm.1585

[103]Zhang, Q., Vonderembse, M. A., \& Lim, J. (2006). Spanning flexibility: supply chain information dissemination drives strategy development and customer satisfaction. Supply Chain Management: An International Journal, 11(5), 390-399. doi:10.1108/13598540610682408

[104]Zulkiffli, S. N. 'Atikah, \& Perera, N. (2011). A Literature Analysis on Business Performance for SMEs: Subjective or Objective Measures? SSRN Electronic Journal. doi:10.2139/ssrn.1867874 